\title{
أثر التوحيد في السعادة عند ابن قيم الجوزية
}

\section{THE EFFECT OF MONOTHEISM ON HAPPINESS ACCORDING TO IBN QAYYIM AL-JAWZIYYA}

\author{
Achmad Reza Hutama Al Faruqi ${ }^{1}$ \\ Universitas Darussalam Gontor
}

\author{
Aqmarina Shofita ${ }^{2}$ \\ Universitas Darussalam Gontor
}

\author{
Filaila Nur Faiza ${ }^{3}$ \\ Universitas Darussalam Gontor
}

hutama@unida.gontor.ac.id

aqmarinashofita47@gmail.com

faizafila33@gmail.com

\begin{abstract}
Most Muslims used the Western ways to get happiness and did not open their eyes and hearts to a review of ideas about the true happiness in the portrayal of Islam itself and appears in the closure of the Islamic scientific cabinets until it leads to the separation of faith from unification and Happiness. . The study of this research is using the method of Sufism, a kind of Library Research, its purpose is to understand the true meaning of Tauhid and happiness in Ibn Qayyim, and to analyze it in some Muslim scholars, using the descriptive analysis method. The researcher found that Tauhid has the highest place in happiness. Because Tauhid is the belief in God's unity and non-existence. Tawheed is divided into three sections: the Tauhid of rububiyah, the Tauhid of uluhiyah, the Tauhid of Asma wa ash-shifat. The concept of happiness when the son of the values of the nut is the feeling near to God as if he was lying before his Lord, and was the happiness of the son of the values of the nut. And happiness has two types: the earthly happiness and the happiness of the Acharonism. Happiness is divided into three sections: external, physical, and psychological and spiritual happiness heart.
\end{abstract}

Keywords: Tauhid, Happiness, Ibn Qayyim al-Jauziyah, Sufi Discourse.

ABSTRAK: Sebagian besar umat Islam dewasa ini menggunakan cara-cara Barat dibanding ajaran Islam dalam mencari atau mendapatkan kebahagiaan. Mereka enggan untuk meninjau gagasan tentang kebahagiaan sejati dalam penggambaran ajaran Islam itu sendiri. Mereka kerap muncul dan menutup "lemari ilmiah" Islam sehingga mengarah pada pemisahan antara Iman dan Kebahagiaan. Kajian dalam penelitian ini menggunakan metode tasawuf jenis Library Research yang bertujuan untuk memahami makna Tauhid dan kebahagiaan yang hakiki dalam perspektif Ibnu Qayyim, dan menganalisisnya pada sebagian ulama dengan menggunakan metode analisis deskriptif. Peneliti menemukan bahwa Tauhid memiliki tempat tertinggi dalam kebahagiaan. Karena Tauhid adalah keyakinan akan keesaan Tuhan. Tauhid dibagi menjadi tiga bagian: Tauhid rububiyah, Tauhid uluhiyah, Tauhid Asma wa ash-shifat. Konsep kebahagiaan dari tauhid adalah merasa berbahagia karena senantiasa merasa dekat dengan Tuhannya, seolah-olah Tuhan selalu berada di hadapannya dan tidak bisa dipisahkan dari kehidupannya. Kebahagiaan memiliki dua jenis: kebahagiaan duniawi dan kebahagiaan Acharonisme. Kebahagiaan dibagi menjadi tiga bagian: eksternal, fisik, dan psikologis dan kebahagiaan hati spiritual.

Kata Kunci: Tauhid, Kebahagiaan, Ibn Qayyim al-Jauziyah, Kajian Sufi. 
السعادة بمعنى الحظ أو الشعور الهادئ بالسعادة (خالية من كل شيء مزعجة). 1 والسعادة هي المتعة

وسلام الحياة (الظاهرة والباطنة)، الحظ الجسدي والروحي. وكلمة سعيدة في اللغة العربية تعني السعادة "الحظ" أو "السعادة".2 السعادة هي دراسة دافئة ليتمّ فحصها من قبل علماء النفس. لأنّ السعادة هي كلمة غالبا ما يتم التحدث بها حتى في الحياة البشرية، ولكن كثيرون لايزال ممن لم يجدوا السعادة في حياقم. حاول علماء النفس إعادة صياغة معنى وعناصر السعادة. ومع ذلك، فإنّ هؤلاء الخبراء يعانون أيضا من الارتباك الحقيقي وشكل من أشكال السعادة في المجتمع الغربي. 3 وكان السعادة عند الفاربي، هي حين الروح الإنسانية يكون كاملا في شكل، حيث لايحتاج في

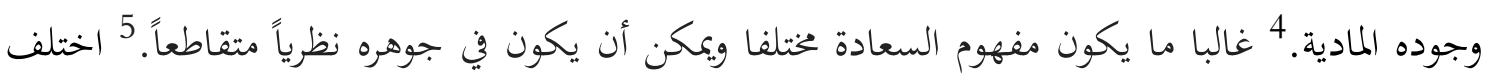
الناس في حصول السعادة على مستوى جهدهم في السعي على تناول السعادة الدنيوية والأخروية. والسعادة له أثر كبير في الحياة، لأنّ يستطع أن يفسد العقيدة ويضاع صور الحق في الإسلامي. وقد أصيب كثيرا من الناس إمّا الأغنياء أو الفقراء بهذه السعادة ولا يعرفون كيف الطرق في حصولها. وهل استخدم الطرق الغربي لحصولها كان كافيا ومطابقا بأحوال الناس في هذا الزمان الذين غفلوا عن حقيقة السعادة. وكان ابن القيم من أحد العلماء المشهورين له المنهج الخاص عن السعادة. استنادا إلى ما ورد أعلاه، تعرض إلى عدد من الأسئلة التي تمكن أن تطلب، كيف كان أثر التوحيد في السعادة عند ابن قيم الجوزية؟ و كيف حصول إلى السعادة الحقيقية؟ فالإجابات هذه الأسئلة سوف تكون الحجة وبينة على أن هذا البحث حازم ومعقول ولا يمكن تفويتها في الدراسة للعقيدة والفلسفة الإسلامية. لذلك كان التوحيد هو شيء أفضل، لازم معروف ومقوم لعبده لحصول إلى السعادة الدنيوية والأخروية. ومن تلك المشقة، أراد الباحثة عن تحليل المشكلة. كيف كان أثر التوحيد في السعادة عند ابن قيم الجوزية؟

${ }^{1}$ Departemen Pendidikan dan Kebudayaan, Kamus Besar Bahasa Indonesia, (Jakarta: BalaiPustaka, 1990), 65.

2 Jalaluddin Rakhmat, Renungan-Renungan Sufistik: Membuka Tirai Kegaiban, (Bandung: PTMizan Pustaka, 1994), 205.

${ }^{3}$ Ruud Veenhoven, "How Do We Assess How Happy We Are?", Paper Presented at Conference on 'New Directions in the Study of Happiness: United States and International Perspectives, University of Notre Dame, USA, October, 22-24,2006

${ }^{4}$ Ibrahim Madkour, Filsafat Islam: Metode dan Penerapan, terj. Yudian Wahyudi dkk, (Jakarta:PT RajaGrafindo Persada, 1996), bagian 1, cet. ke-4, 32.

${ }^{5}$ Shigehiro Oishi \& Ed Diener, Journal Association For Psychological Science, Vol. 2, Number 4, 2007, 346 . 
هذه الدراسة من نوع الدراسة المكتبية التي تقصد بها جميع المعلومات والبيانات باستخدام مختلف المواد في المكتبة " Library Research" بمدخل الكيفي. والبحث الذي قدمته الباحثة باستخدام منهج الوصفي والتحليلي، وهو التحليل في الأفكار المتعلقة باستخدام أساليب التوحيد أساس في السعادة عند إبن قيم الجوزي التي لم تمس في عالم الفكر الغربي. ومن أجل تحليل الحقائق التي حصلت الباحثة في هذا البحث فسار على المناهج الآتية: المنهج الوصفي (Descriptive Method), واستخدمت الباحثة هذا المنهج للوصول إلى معرفة ترجمة حياة ابن قيم الجوزية. المنهج التحليلي (Analytic Method), واستخدامت الباحثة هذا المنهج لتحليل المسائل المتعلقة بنظرية ابن قيم الجوزية في مسألة التوحيد والسعادة، ثم مناقشتها للوصول إلى استنباط صحيح. التوحيد عند العلماء

ومعنى التوحيد عند ابن تيمية6 هو أن يوجه المسلم في عبادة الله وحده ولايعبد غيره ويوحّد الله بعمل عبده بنيّة التقرّب إلى الله المشروع. ذهب ابن تيمية في اثبات التوحيد إلى منهج حيث يقسمه إلى ثلاثة أنواع:7 توحيد الربوبية، توحيد الألوهية، وتوحيد الأسماء والصفات. نئ. يرى الأشعري بأنّ الله تعالى كالخالق يتصف بالوحدانيته، لأنّه إذا وجد الإله أكثر من واحد فسوف يحدث الفوضى في العالم ومخلوقاته. وعندما وجد الإلمان، فالواحد يريد الشيء حيا والآخر يريده موتا، وسيكون ثلاثة ممكنات. أولا تلك الإرادتين واقعتان في آن واحد، وهذا مستحيل أن يكون الموت والحياة في آن واحد، والثاني تلك الإرادتين غير حادثتين، إذن كلاهما ضعيفتان، والضعيف لم يكن إلها ولاقديما، والثالث: كانت إرادة الإله واقعة والآخر غير واقعة، ولذلك فالإله ولهيك الثانى ضعيف، والضعيف لا يمكن أن يكون إلمًا الذي يتصف وبالقدم.

6 وهو من العلماء البارزين، والشيخ الإسلام، ولد ابن تيمية بحران من أعمال أورفه في تركيا سنة 661 هـ وهاجر

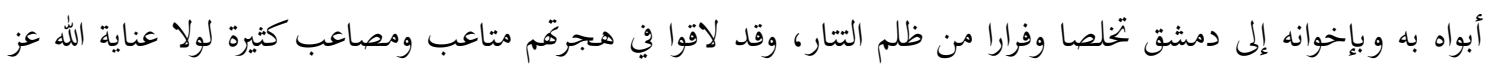

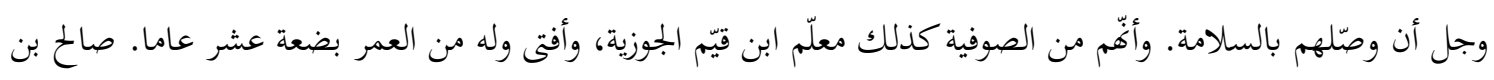

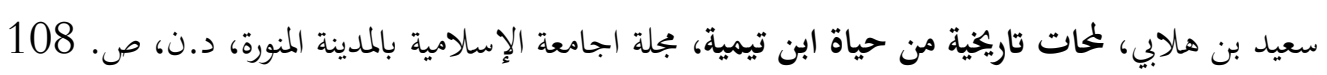
7 محمد السيد الجليند، قضية التوحيد بين الدين والفلسفة، (القاهرة: مكتبة الشباب، الطبعة الرابعة، 1986

$$
\text { هـ)، ص.101 }
$$

8 أمل فتح الله زركشي، عقيدة التوحيد عند افلاسفة والمتكلمين والصوفية، (فونوروكو: جامعة دار السلام

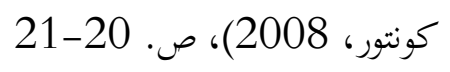


أما أبو حامد الغزالى في كتابه إحياء علوم الدين، الجز الأول، يقول أنّ التوحيد هو الجوهر

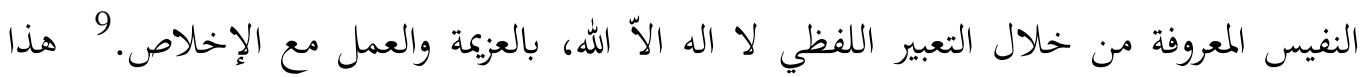

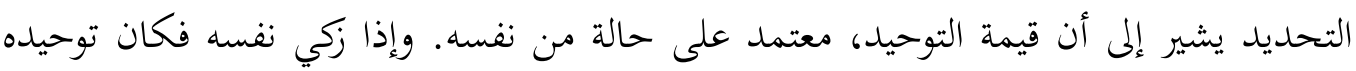

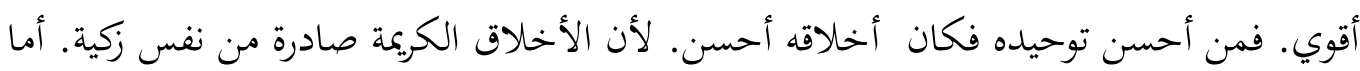

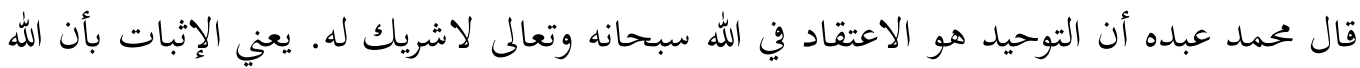
هو واحد، ويشمل على وحدانية الله في ذاته، وعمله، وخلقه، وعلى كل شيء. 10

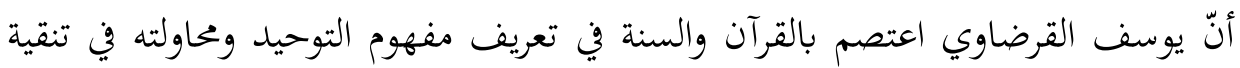

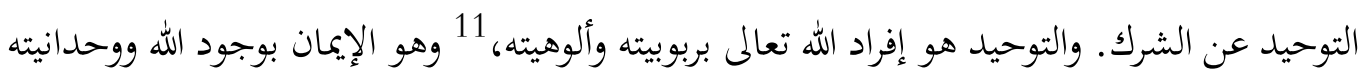

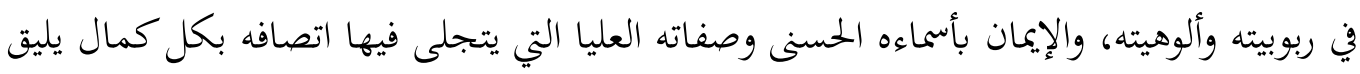

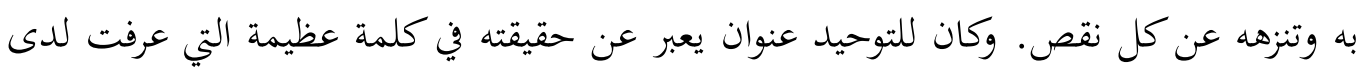

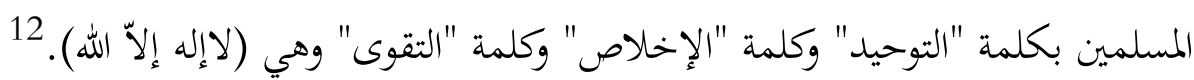

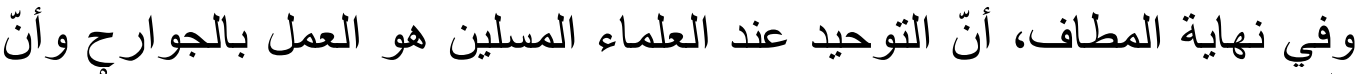

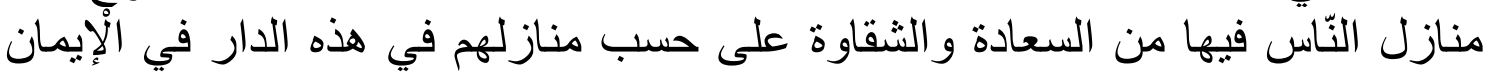
و العمل الصالح وضدهما. السعادة عند العلماء المسلمين

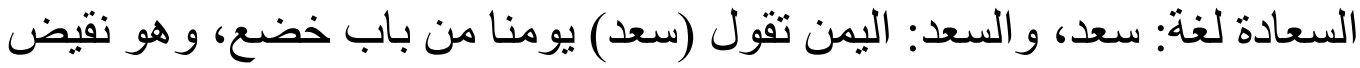

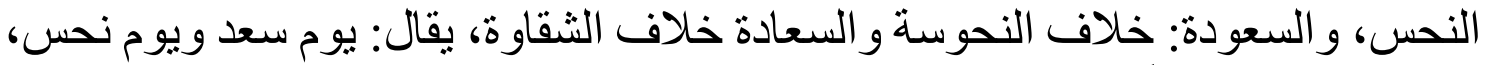

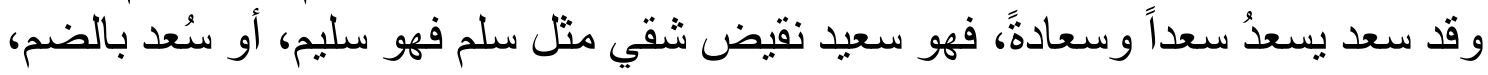

9 في هذا الصدد، ينقسم الغزإلى التوحيد إلى أربعة مستويات، وهي التوحيد للمنافين، والتوحيد الشائع للمسلمين،

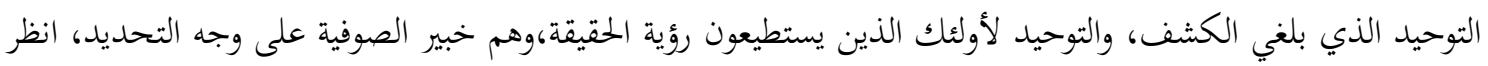

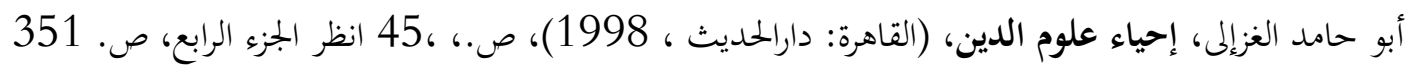

$$
10
$$

11 يوسف القرضاوي، ملامح الجتمع المسلم الذي ننشده، (مصر: مكتبة وهبة، الطبعة الثالثة 1422 هـ)،

12 يوسف القرضاوي، الإيمان و الحياة، (القاهرة: مكتبة وهبة، الطبعة العاشرة 1416 هـ)، ص. 28 


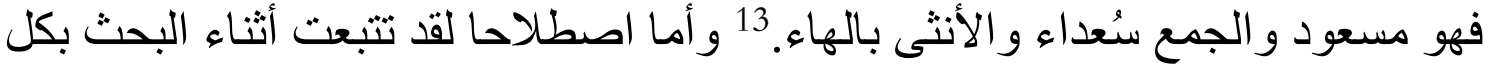

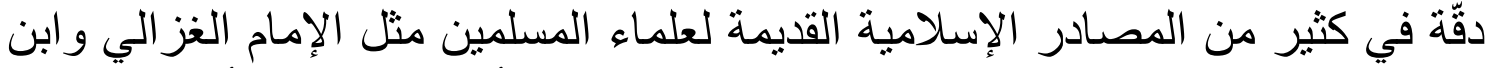

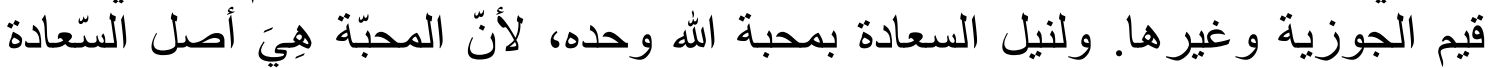

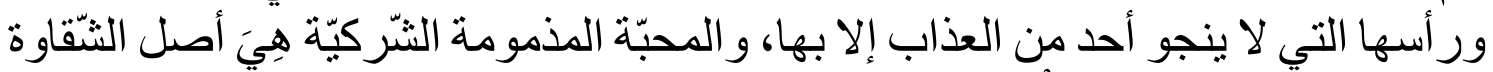

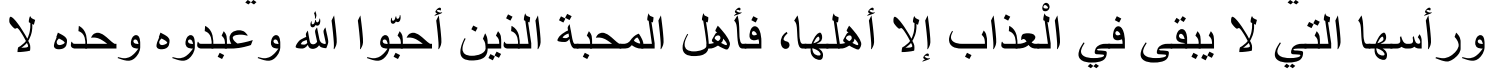

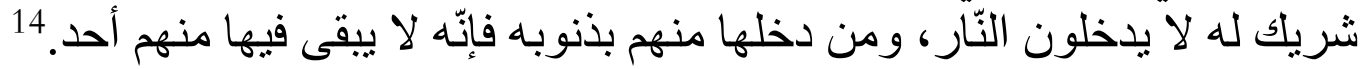
السعادة عند ابن تيمية هي سعادة النفوس كمالها علمًا وعملاً، هم من أبعد الناس عن هذا، وذلك لنك

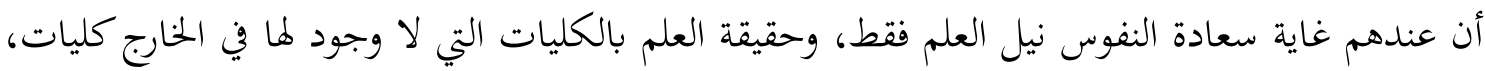

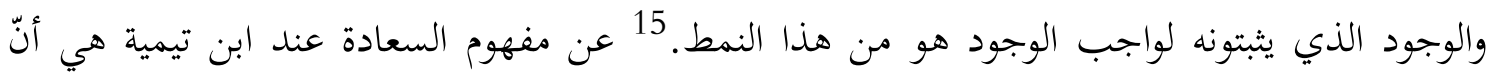

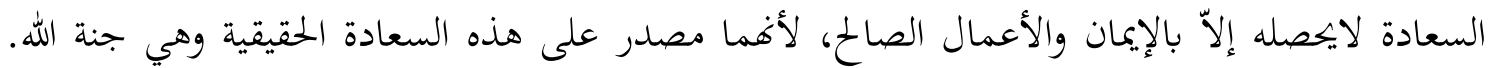

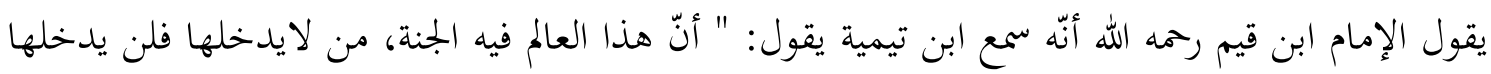

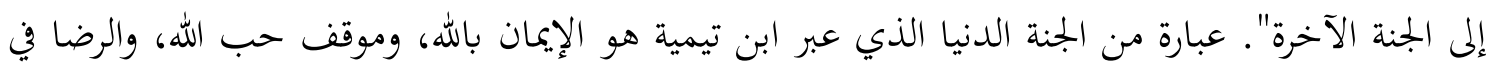
أحكامه.

إنّ السعادة عند الإمام الغزالي مبني على ثلاثة أشياء: قوة الغضب وقوة الشهوة وقوة العلم وكان أول

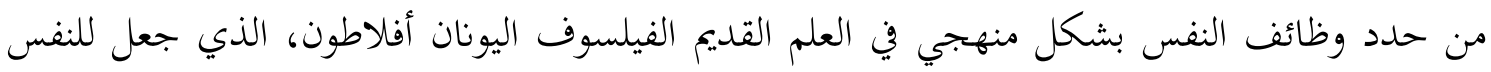
ثلاثة قوى: القوة الشهوانية والقوة العاقلة، وجعل النفس الشهوانية والنفس الغضبية تابعتين وخادمتين للنفس لتس العاقلة، وقد شبه أفلاطون الإنسان وقواه وعناصره المختلفة بالمدينة الفاضلة التي كان يسعي إلى تأسيسها، حيث جعل سكان مدينته ثلاث طبقات: طبقة العمال وطبقة المحاريين وطبقة الحكام، فجعل طبقة العمال

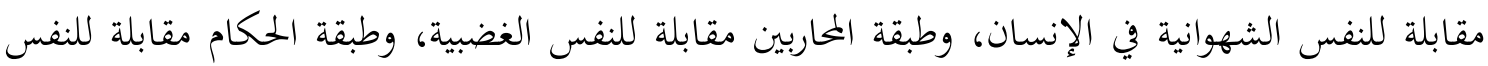

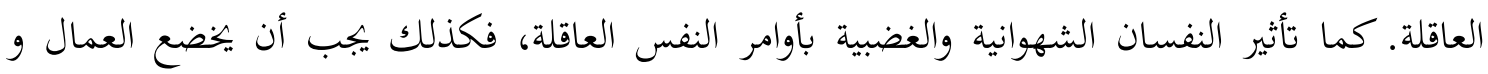
المحاربون للحكم الذين يجب أن يكونوا من الفلاسفة برأيه. 16

13 عبد الله محمد غانم العامري، السعادة في المنظور الإسلام، (بيروت-لبنان: دار ابن حزم، 2005م)، الطبعة

الأولى، ص. 28-29 (29

14 ابن قيم الجوزية ، الجواب الكافي لمن سأل عن الدواء الشافي أو الداء والدواء، (المغرب: دار المعرفة،

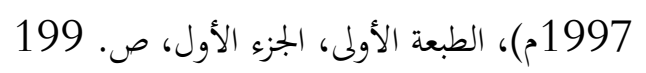

$$
15
$$

16 الإمام الغزالي، كيمياء السعادة، في بجموعة رسائل الإمام الغزالى، (بيروت: دار الكتب العلمية، 1988)، 
كانت السعادة عند ابن مسكويه هو نظرية الوسط التي يثق بها ويطمئنّ إلى سلامتها كل الاطمئنان

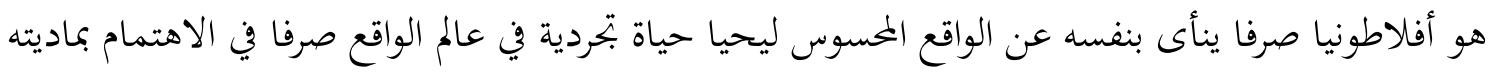

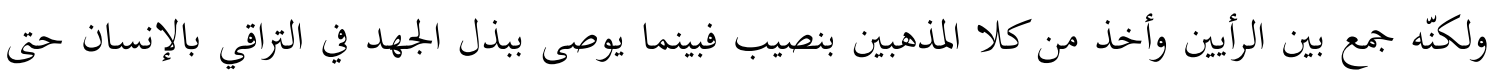

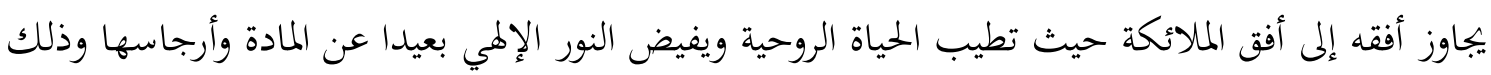

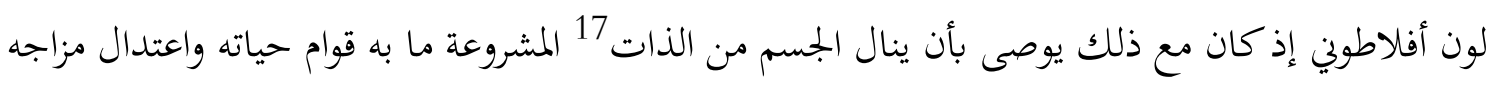

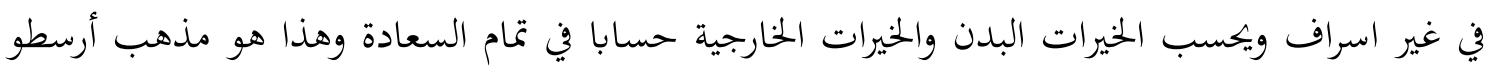

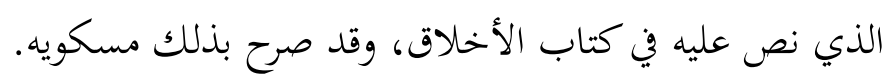

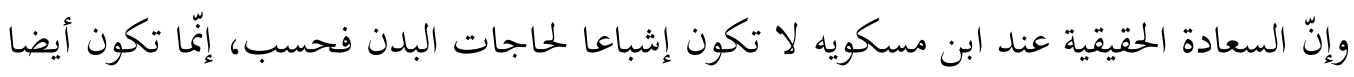

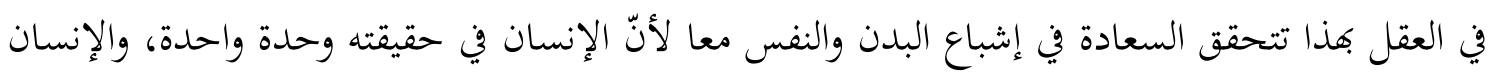

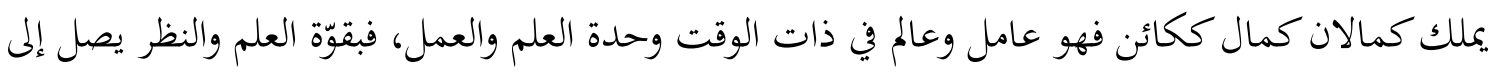

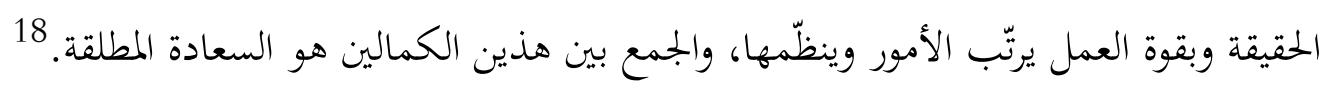
لمحة عن تاريخ عن ابن قيم الجوزية

الإمام المققق البارع الفذ المتقن المتفنن "شمس الدين أبو عبد الله محمد ابن أبي بكر بن أيوب بن

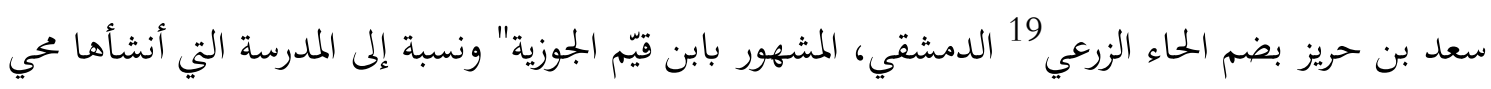
الدين أبو المحاسن يوسف بن عبد الماء لزرعي الرمن بن علي بن الجموزي.

17 ابن مسكويه، تمذيب الأخلاق في التربية، الطبعة الأولى،(بيروت-لبنان: دار الكتب العلمية، 1405 هـ-

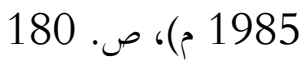

$$
18 \text { 18 المرجع السابق، ص. } 189
$$

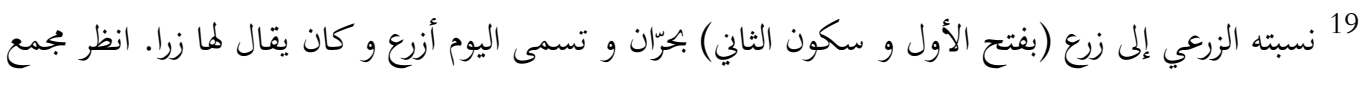

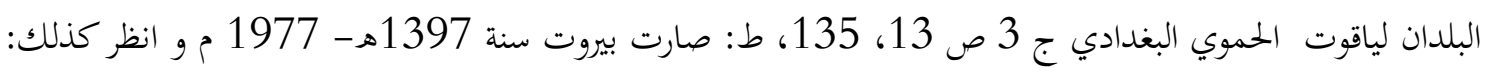

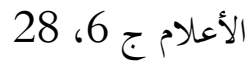

20

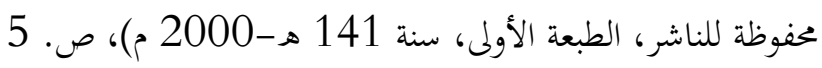


YAQZHAN | Volume 07, Nomor 02, Desember 2021

كان ابن قيم فقهيا حنبليا متكلما، وكانت له آراء في التصوف على طريقة السلفية التى تقرر فكرة التصوف في اعتدال، دون مغالاة أو ابتدع. 21 ولد ابن قيم في بيت علم وفضل في السابع من صفر سنة إحدى وتسعين وستمائة (691 هـ)، في قرية زريع ويقال له اليوم أزرع، من قرى حوادث التابعين لحرّان وكفى تبعد عن مدينة دمشق خمسة وخمسين ميلا جنوب شرقها. 22 وقد أثبت البحث العلمي الحديث أنّ الشخص بتأثر بالأحوال والظروف المحبطة به، كما يتأثر بالبيئة التي يعيش فيها، ويكون لها دخل كبير في تكييف حياته، وطبعها بطابع خاص، فنوع التربية التى يتلقنها في البيت وين المدرسة، والروح العامة التى تسود أساتذته ومعليه، والتلاميذ الذين يهيطونه ويعاشرون، والكتب التي يقرأها، والأحوال الاجتماعية والسياسية والاقتصادية التي توجد في عصره، كل أولئك عوامل مهمة في تكوين شخصيته وتكييف اتجاهها وتعيين طريقها ومنهجها. وكان لهذا آثار في الحياة الثقافية والاجتماعية والسياسية لعصره. كان ابن قيم عارفاً بالتفسير لا يجّارى فيه، وبأصول الدين، وإليه فيه المنتهى، والحديث ومعانيه وفقهه ودقائق الاستباط منه لا يلحق في ذلك، وبالفقه وأصوله، وبالعربية وله فيها اليد الطولى، وعلم الكلام والنحو، وغير ذلك، وكان عالماً بعلم السلوك، "ولا رأيت أوسع منه علماً، ولا أعرف بمعاني القرآن والسنة وحقائق الإيمان أعلم منه، وليس نمو المعصوم، ولكن لم أرى في معناه مثله." ولقد اتصف رحمه الله بصفات كثيرة لايتسع المقام لذكرها منها على سبيل المثال أنه ذا عبادة والزهد، التقوى، النقاء، وعدم الحقد والحسد، فقد كان عابداً زاهداً تقيًا نقيًا، حسن الخلق، كثير التواد، لا لا يحسد أحدًا ولا يؤذيه، ولا يستعيبه، ولا يحقد على أحد. 23 إنّه هو ابن قيم الجوزية من المجتهدين المصلحين الذين لا يترددون في نقد كثير من آراء أهل العصر بنظر العقل الذي لا يخالف الشرع. وهو يفعل ذلك في هدوء وصبر، وترتيب منظم لما يعرض من أفكار، مع ميل إلى مقارنة والموازنة. التوحيد عند ابن قيم الجموزية

21 عمر أحمد الراوي، طب القلوب عند الإمامين الجليلين ابن تيمية الحراين و ابن قيم الجوزية، الطباعة الأولى،

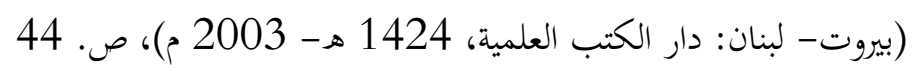
22 مصطفي مراد صبحي محمد، موقف الإمام ابن قيم من الصوفية.... ص. 8 23 ابن كثير، البداية والنهاية، (قاهرة: سنة 14-8 هـ)، المجلد 14، ص. 246 


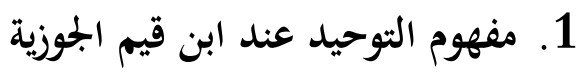

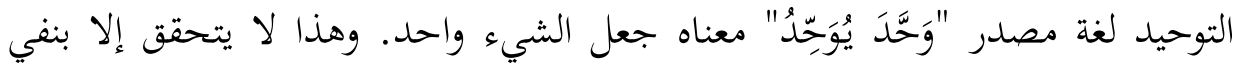
وإثبات، نفي الحكم عما سوى الموحد وإثباته له. ومعناه الإصطلاحا هو العلم والاعتراف بتفرّد

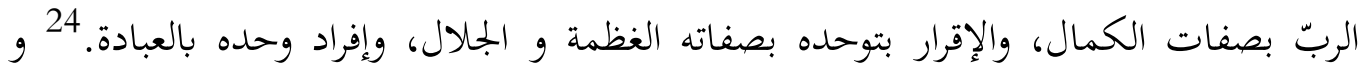

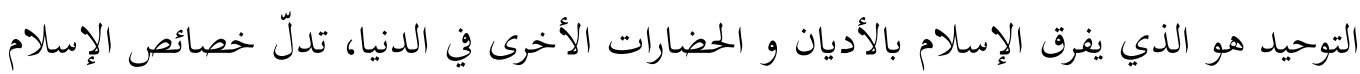
على أنّه دين كامل بالنسبة إلى الأديان الأخرى. 25

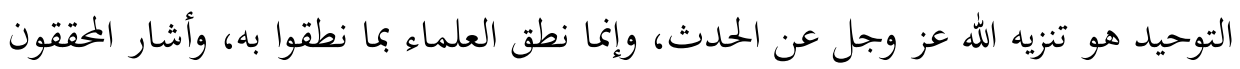

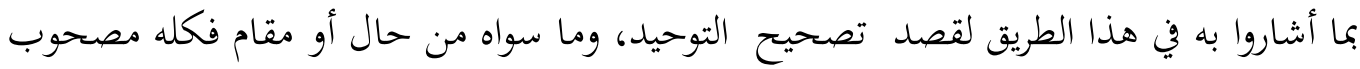

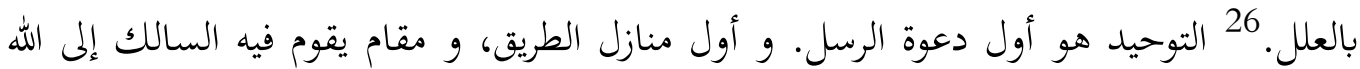

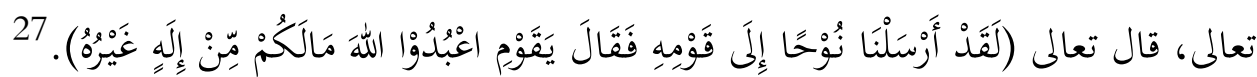

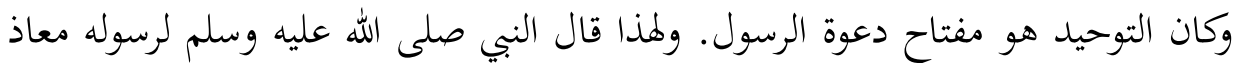

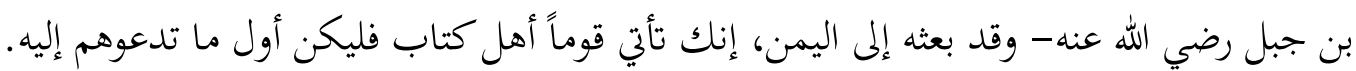

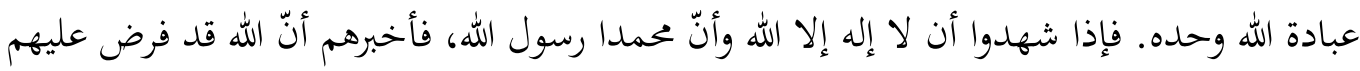

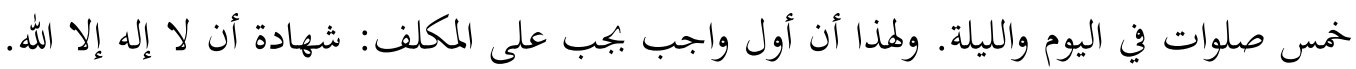
لا النظر، ولا القصد إلى النظر، ولا الشك كما هي أقوال لأرباب الكلام المدام المدوم. 28

24 24 حمد بن عبد الوهاب، كتاب التوحيد، كتاب التوحيد، الطبعة الأولى، مصر: مكتبة عباد الرمن،

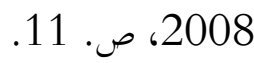
25 يوسوف القرضاوي، حقيقة التوحيد، (القاهرة: مكتبة وهبة، الطبعة السابعة، 1409 هـ)، ص.

26 ابن قيم الجوزية، مدارج السالكين بين منازل إياك نعبد وإياك نستعين ، الجزء 3، بيروت-لبنان،

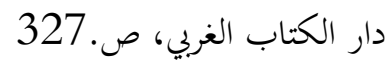
27 28 28 إبن قيم الجوزية، مدارج السالكين...، ص. 411 
والتوحيد كذالك أول ما يدخل به الإسلام، وآخر ما يخرج به من الدنيا. كما قال النبي

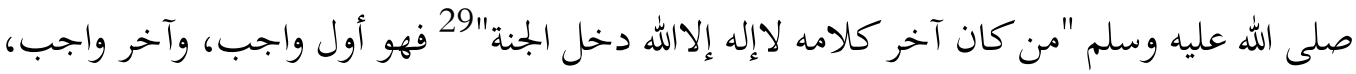
فالتوحيد أول الأمر وآخره.

قوله " التوحيدُ هو تنزيه الله عن الحدث "، هذا الحد لا يدل على التوحيد الذي بعث الله

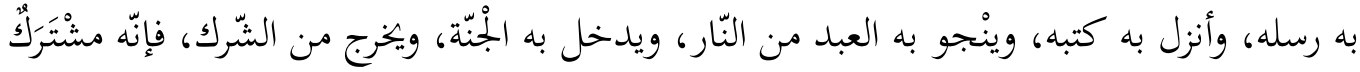

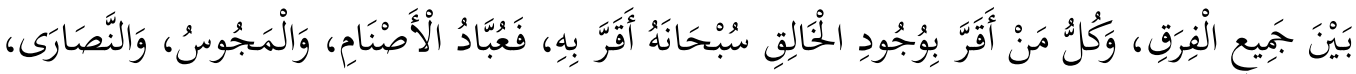

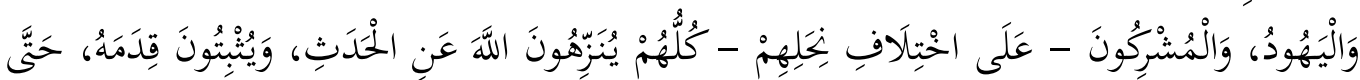

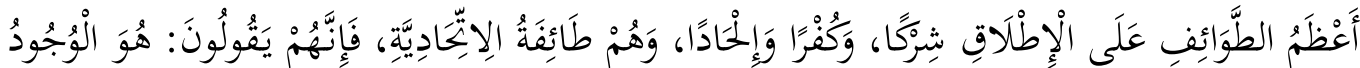

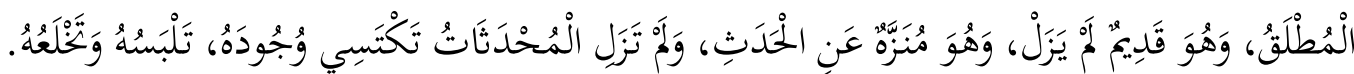
فقال ابن تيمية على أن التوحيد الذي جاءت به الرسول من أولهم إلى آخرهم، ونزلت بهن الكتب كلها. وبه أمر الله الأوليين والآخرين. وقال "من مات وهو يعلم أن لاإله إلا الله، دخل

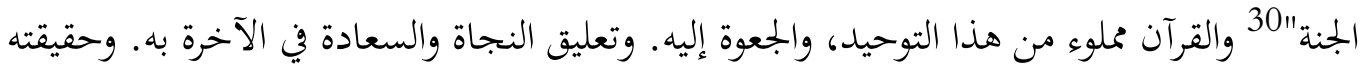
إخلاص الدين كله الله. 31 والفناء في هذا التوحيد مقرون بالبقاء. وعنده كذالك أن التوحيد هو ضد من الشرك، إذا قام العبد بالتوحيد الذي هو حق الله

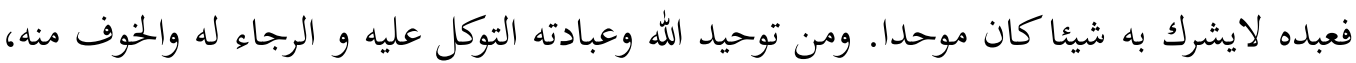
فهذا يخلص به العبد من الشرك. و التوحيد الله و إخلاص الدين له في عبادته و استعانته في القرآن كثيرا جدا. بل هو قلب الإيمان وأول الإسلام و آخره.

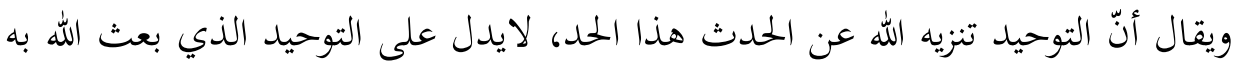
رسله، وأنزل به كتبه. وينجو به العبد من النار، ويدخل به الجنة. ويخرج من الشرك، فإنه مشترك بين الشين

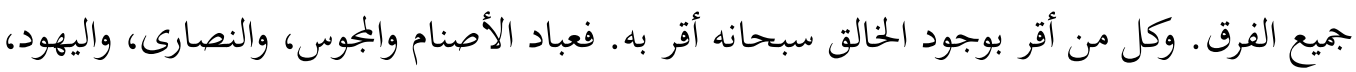

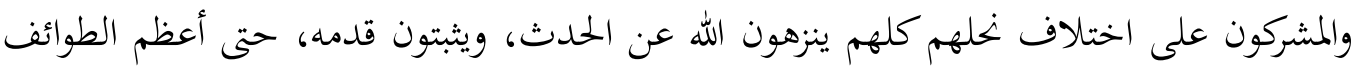

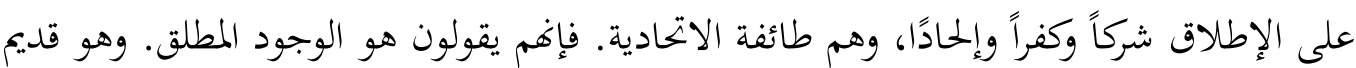
لم يزل وهو منزه عن الحدث ولم تزل المحدثات تكتسي وجوده، تلبسه وتخلعه.$$
29 \text { أخرجه أبو داود في كتاب: الجنائز، باب في التلقين (3116). }
$$$$
30 \text { أخرجه مسلم في كتاب الإميان، باب الدليل على أن من مات على التوحيد دخل الجنة، ص. }
$$ 
والفلاسفة الذين هم أبعد الخلق عن الشرائع وما جاءت به الأنبياء يثبتون واجب الوجود

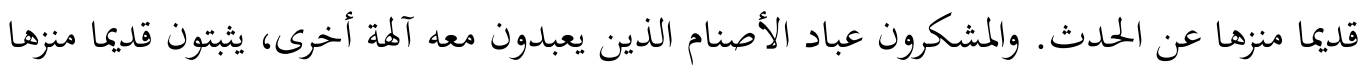

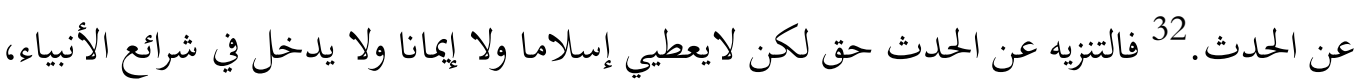

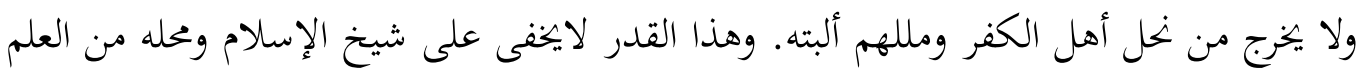
والمعرفة محله.

القلب لا يستقر ولا يطمئن ويسكن إلاّ بالوصول إلى التوحيد، وكل ما سواه مما يجب ويراد

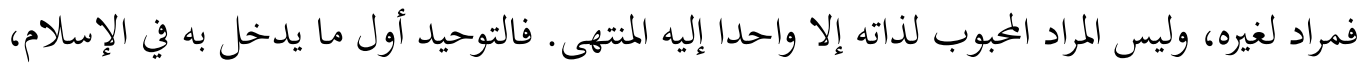
وآخر ما يخرج به من الدنيا كما قال النبي صلى الله عليه وسلم: من كان آخر كلامه لاإله إلا الله

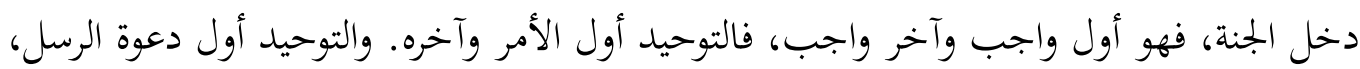
وأول منازل الطريق وأول مقام يقوم فيه السالك إلى الله تعالى.

\section{2. أقسام التوحيد عند ابن قيم الجوزية}

كان ابن قيم الجوزية يقسم التوحيد إلى أنواع: فالنوع الأول منه هو ما عناه ابن قيم، التهابه

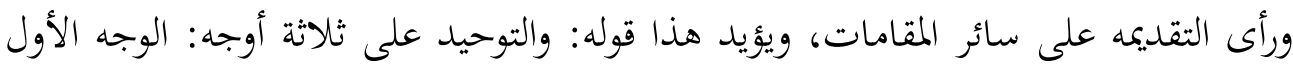

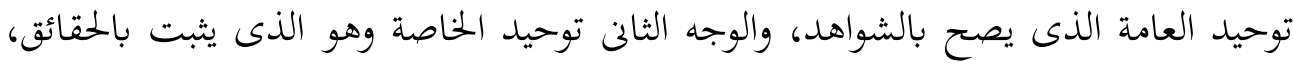

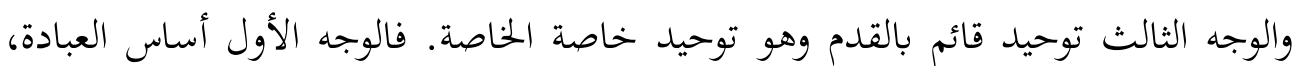

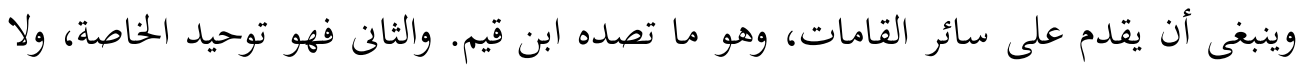

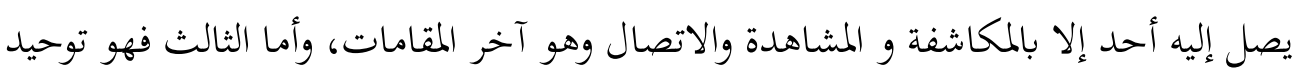
الله نفسه.

والتوحيد يتمثل في الشهادة أن لا إله إلا الله: نطقا بها، وعملا بمقتضاها نفيا و إثباتا،

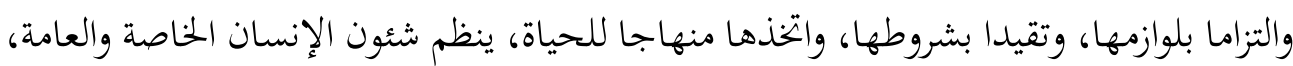

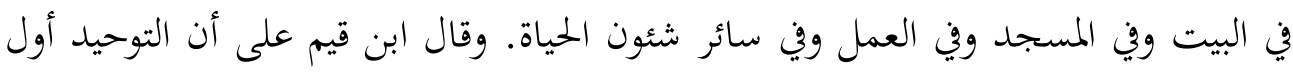

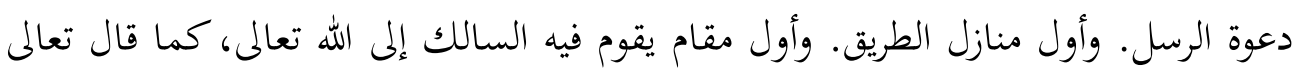

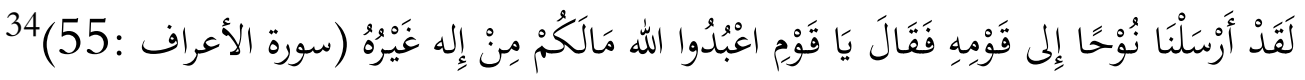

$$
\begin{aligned}
& 32 \text { المرجع السابق، ص. } 326 \\
& 33 \text { المرجع السابق، ص. } 478 \\
& \text { للتشر، } 1415 \text { ه)، ص. } 6
\end{aligned}
$$


وأنه كذلك مزق بسهولة، ملوث، وملطخ من اللوم، و أنه الملابس البيضاء التي

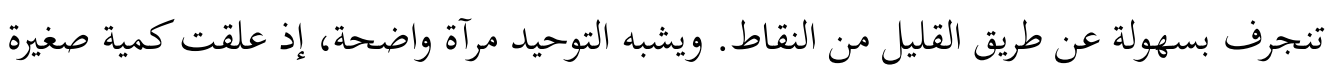
من العصي البقع ستعطي بالتأكيد علامات على سطحه.

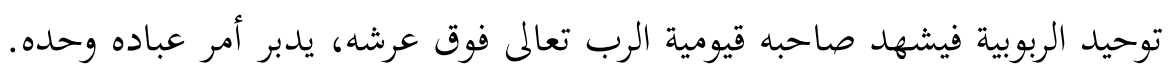

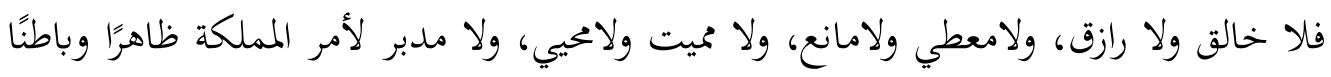

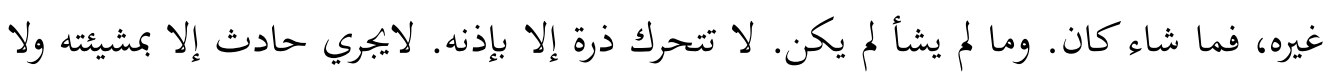

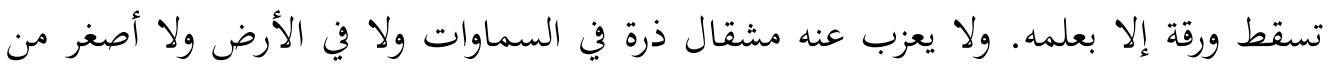

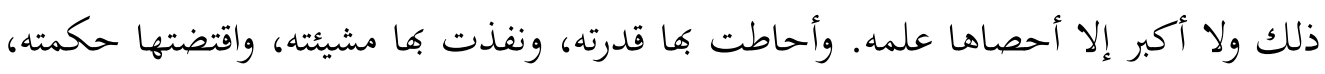

$$
\text { فهذا جمع توحيد الربوبية. }
$$

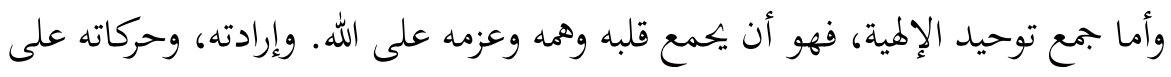

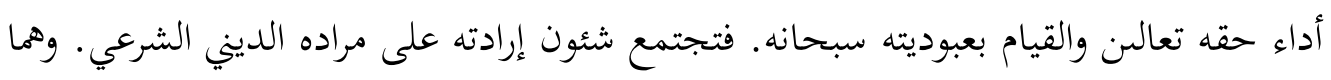
يجمعان في كلمة إياك نعبد وإياك نستعين. 35

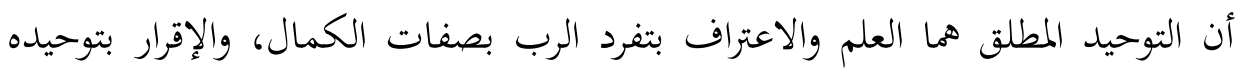

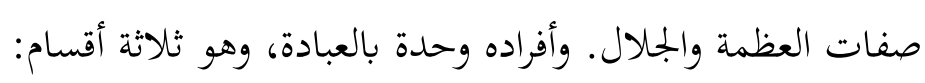

$$
\text { أ. أتوحيد الربوبية }
$$

بان يعتقد العبد ان الله الرب المتفرد بالخلق والرزق والتدبير الذي ربي جميع

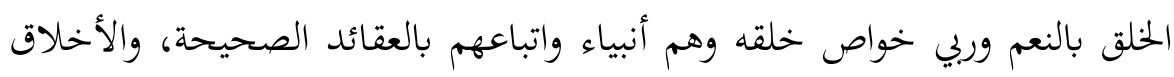

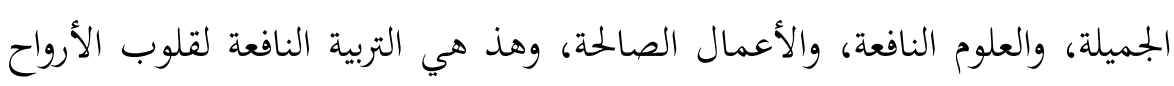

$$
\text { المثمرة لسعادة الدين. }
$$

\section{ب. التوحيد الألوهية ويقال له توحيد العبادة}

وهو العلم والاعتراف بان الله ذو الألوهية والعبودية على خلقه أجمعين وإفراده

$$
\begin{aligned}
& \text { وحده بالعبادة كلها وإخلاصه الديني لله وحده. } \\
& \text { ت. التوحيد الأسماء والصفات }
\end{aligned}
$$

وهو اعتقاد انفراد الرب جل جلاله بالكمال المطلق من جميع الوجود بعنوت

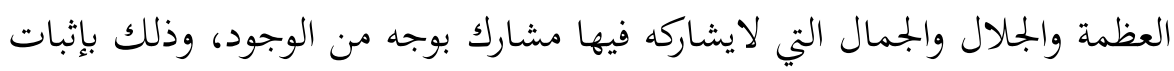

$$
35 \text { إبن قيم الجوزية، مدارج السالكين..... ص. } 374
$$




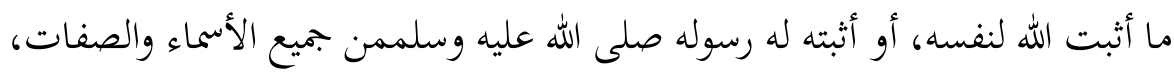

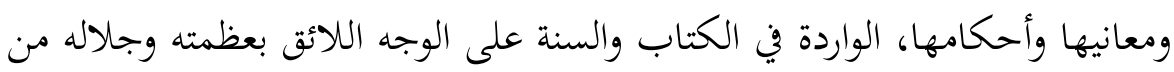

$$
\text { غير نفي لشيء منها ولا تعطيل ولا تحريف ولا تمثيل. }
$$

وشرح الغزالي في كتابه احياء علوم الدين عن صفات الله كاملا. إن الحمد ولديل

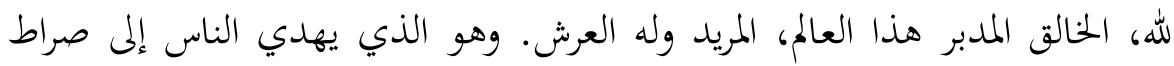

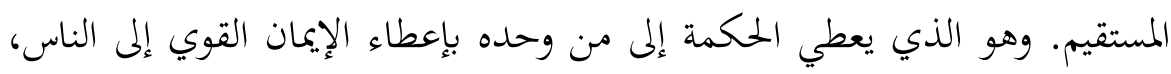

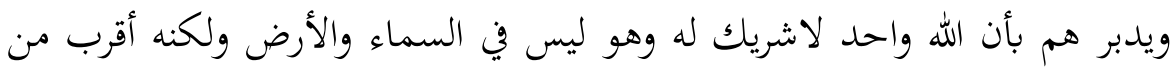

$$
\text { حبل الوريد. }
$$

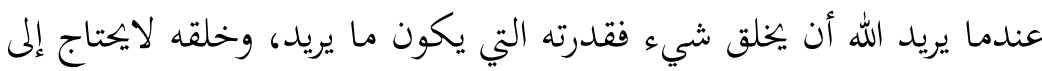

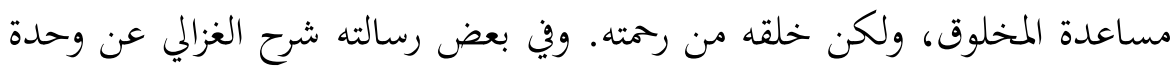
الوجود، بأن كل مخلوق ظهر من إرادته وعظمته.

السعادة عند ابن قيم الجوزية

\section{1. مفهوم السعادة عند ابن قيم الجوزية}

السعادة ضد الشقاوة من كلمة سعد- يسعد كلمة تعظيم تقال لبعض اصحاب

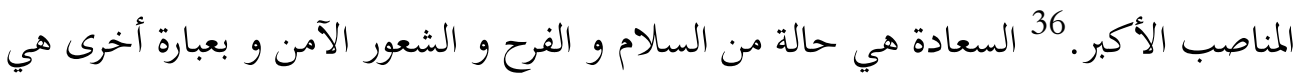

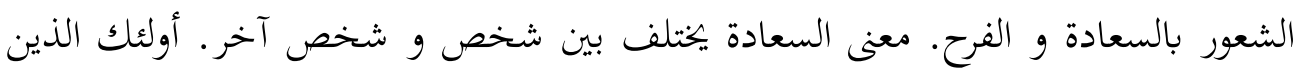

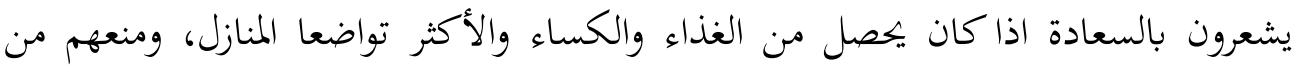

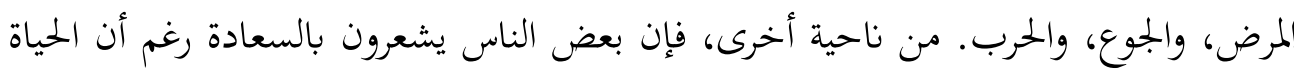

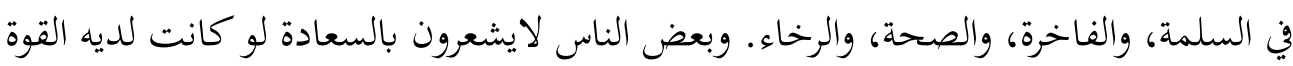
والمكانة والثروة.

يقول الفلاسفة بأن السعادة تنقسم إلى نوعين: أولا، السعادة التلقائية الخالصة وهي

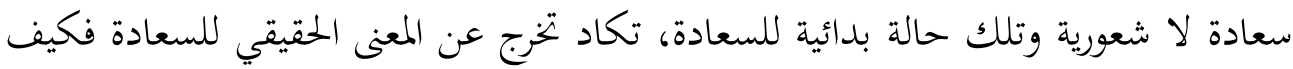

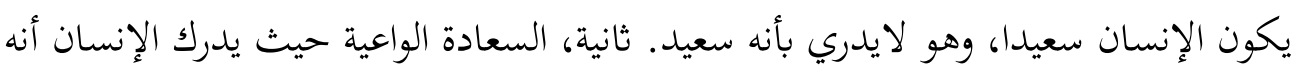

36 أبو لويس معلوف، المنجد في اللغة والأعلام، (بيروت: المكتبة الشرقية، 1986)، ص. 333 
في حالة السعادة وهذا يضاعف من شعور الإنسان بسعادته لكن هناك ما يهدد هذا الإحساس بالسعادة فيقول المحللون: إن الإنسان سرعان ما يقع فريسة القلق على حظه من السعادة. 37 إنّ الله سبحانه وتعالى يستجلب من عبده عن أعظم أسباب السعادة له من استعاذته واستعانته به من شر نفسه وكيد عدوه ومن أنواع الدعاء والتضرع والابتهال والإنابة والفاقة والمحبة والرجاء والخوف وأنواع من كمالات العبد تبلغ به نحو المائة، ومنها ما لاتدركه العبارة وإنما يدرك بوجوده فيحصل للروح بذلك قرب خاص لم يكن يمصل بدون هذه الأسباب ويجد العبد من نفسه كأنه ملقى على باب مولاه بعد أن كان نائيا عنه، وهذا الذي أثمر له أن الله يحب

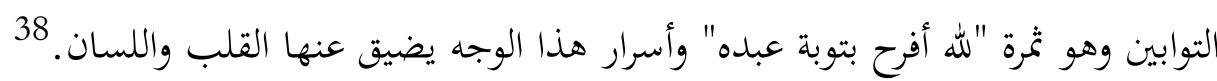
إنّ السعادة تناولها بتمام العبودية، وتمام العبودية هو بتكميل مقام الذل والانقياد وأكمل الخلق عبودية أكملهم ذلا لله وانقيادا وطاعة والعبد ذليل لمولاه الحق بكل وجه من وجوه الذل فهو ذليل لعزه وذليل لقهره وذليل لربوبيته فيه وتصرفه وذليل لإحسانه إليه وإنعامه عليه فإن من أحسن إلينا فقد استبدنا وصار قلبنا معبدا له وذليلا تعبد له لحاجته إليه على مدى ولى ولى وليه الأنفاس في جلب كل ما ينفعه ودفع كل ما يضره. 39 من البيان السابق رأى الباحث أن السعادة عند ابن قيم الجوزية هي الشعور بالقرب إلى الله كأنه ملقّى أمام ربه، رضا بما قسم الله عليه دون قلاقة القلب، وذلك يحصل بتمام العبادة أي بتكميل مقام الذل و الانقياد إلى الله تعالى ولايشركه شيئ، وباستعاذته واستعانته به من شر نفسه وكيد عدوه ومن أنواع الدعاء والتضرع والابتهال والإنابة والفاقة والمحبة والرجاء والخوف وأنواع من كمالات العبد. وعمل ذلك كلها لابد بالعلم وبصحة القلب الروحي لذلك أن العلم وصحة القلب هما شيئان مهمان للحصول إلى السعادة. 2. أنواع السعادة عند ابن قيم الجوزية

37 سعيد صديق عبد الفتاح، السعادة كما يراها المفكرون، (بيروت- لبنان: مؤسسة عز الدين، دون

$$
\text { السنة)، ص. }
$$

38 ابن قيم الجوزية، مفتاح دار السعادة ومنشور ولاية العلم والإدارة، الجزء الأول، (يبروت لبنان: دار الكتب العلمية، 1419 هـ)، ص. 433 39 ابن قيم الجوزية، مفتاح دار السعادة ومنشور ولاية العلم والإدارة...، ص. 300 
السعادة عند ابن قيم الجوزية فيه ثلاثة أنواع: الشكر على النعمة والصبر على البلاء

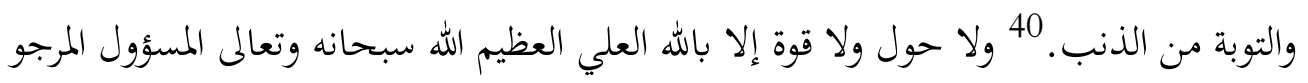
الإجابة أن يتولاكم في الدنيا والآخرة وأن يسبغ عليكم نعمه ظاهرة وباطنة وأن يجعلكم ممن إذا لـا لئه أنعم عليه الشكر وإذا ابتلي صبر وإذا أذنب استغفر فإن هذه الأمور الثلاثة عنوان سعادة العبد وعلامة فلاحه في دنياه وأخراه ولا ينفك عبد عنها أبدا فإن العبد دائم التقلب بين هذه الأطباق

أولا، نعم من الله تترادف عليه فقيدها (الشكر) وهو مبني على ثلاثة أركان: الاعتراف بها باطنا والتحدث بها ظاهرا وتصريفها في مرضاة وليها ومسديها ومعطيها. فإذا فعل ذلك فقد شكرها مع تقصيره في شكرها. أن الشكر من منازل العامة، ولو أن السلطان كسا عبدا من عبيده ثوبا من ثيابه، فأخذ يشكر السلطان على ذلك، لعدّ مخطئاً، مسيئاً للأدب، فإنه مدع بذلك مكافأة السلطان بشكره، فإنّ الشكر مكافأة، والعبد أصغر قدرًا من المكافأة، والشهود للحقيقة يقتضى اتحاد نسبة الأخذ والعطاء، ورجوعها إلى وصف المعطي وقوته، فالخاصة يسقط عندهم السكر بالشهود، وفي حقهم ما هو أعلى منه. ويرى ابن قيم أن منزلة الشكر من أعلى منازل، وهي فوق منزلة الرضى وزيادته، فالرضى

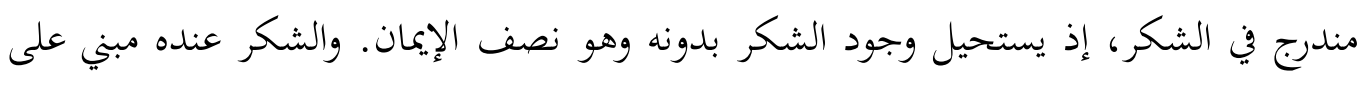
خمس قواعد: خضوع الشاكر للمشكور، وحبه له، واعترافه بنعمته، وثناؤه عليه بها، وأن لا يستعملها

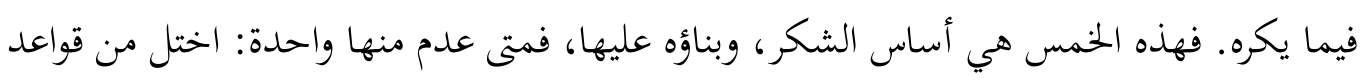
الشكر قاعدة.

وأن الله تعالى أمر به وفى عن ضده، وأثنى على أهله، ووصف به خواص خلقه، وجعله غاية خلقه وأمره، ووعد أهله بأحسن جزائه، وجعله سببا للمزيد من فضله، وحارسا وحافظا لنعمته وله

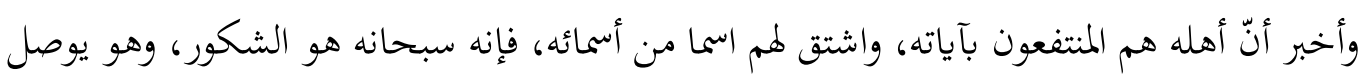
الشاكر إلى مشكوره بل يعيد الشاكر مشكورًا، وهو غاية الرب من عبده، وأهله هم القليل من آنم

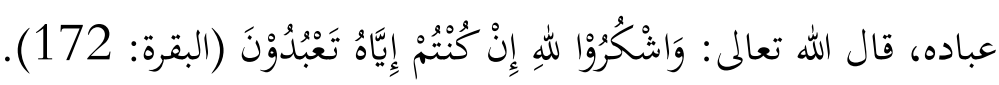

$$
\begin{aligned}
& 40 \text { محمد بن أبي بكر بن أيوب بن سعد شمس الدين ابن قيم الجوزية، الوابل الصيب من الكلم } \\
& \text { الطيب، (القاهرة: دار الحديث، سنة } 1999 \text { م)، ص. } 5 \\
& 41 \text { ابن قيم الجوزية، مدارج السالكين....، ص.249 }
\end{aligned}
$$


أن كمال السعادة واللذة الحقيقية، ترك كل شيء حتى الوجود لأجل أنه جل شأنه هو هو،

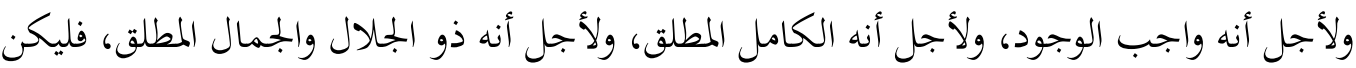

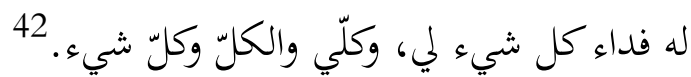

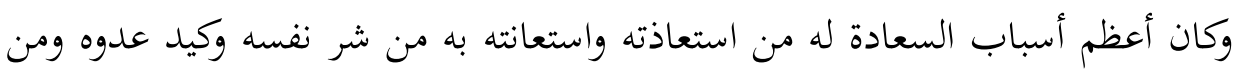

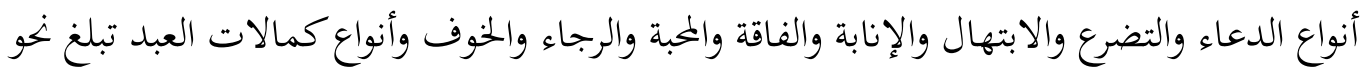

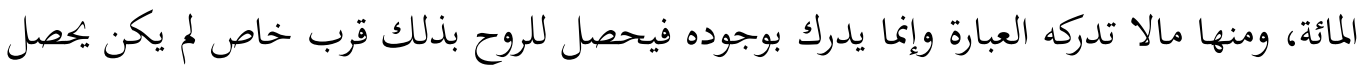

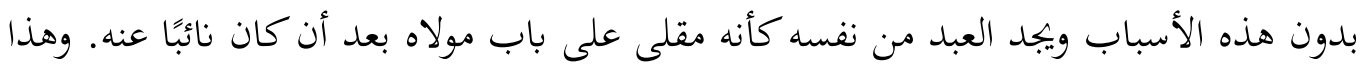
هو أثمر له أن الله يحب التوابين ثمرة "له أفرح بتوبة عبده". 43

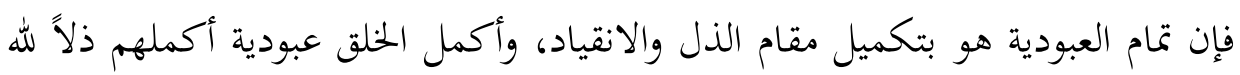
وانقيادًا وطاعة، والعبد ذليل لمولاه الحق بكل وجه من وجوه الذل فهو ذليل لعزة وذليل لقهره وذليل

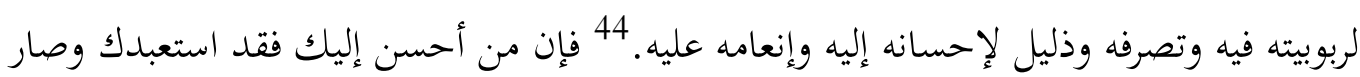

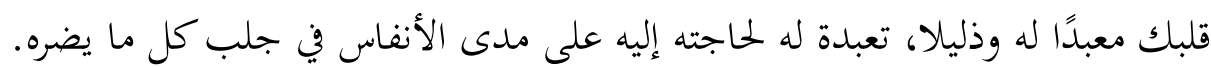

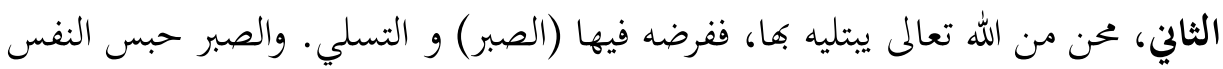

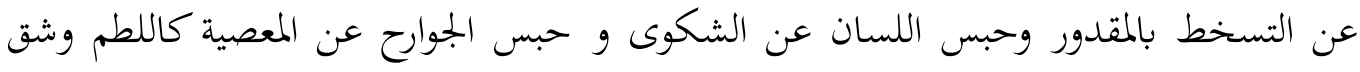

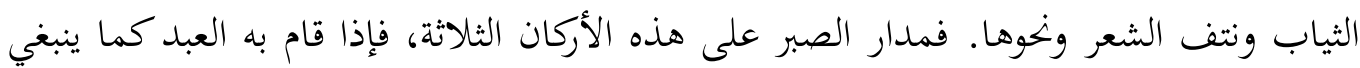
انقلبت المحنة في حقه منحة، واستحالت البلية عطية، وصار المكروه محبوباً.

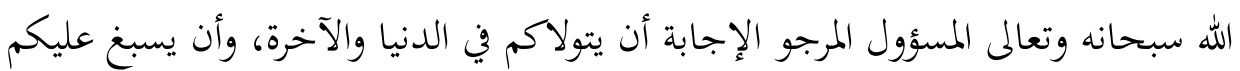

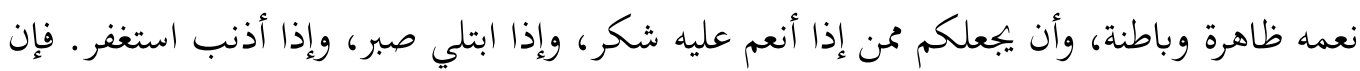
الله سبحانه وتعالى لم يبتله ليهلكه، وإنما ابتلاه ليمتحن صبره وعبوديته، فإن لله تعالى على العبد

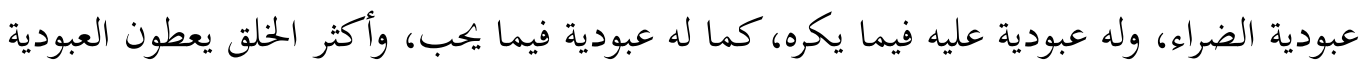

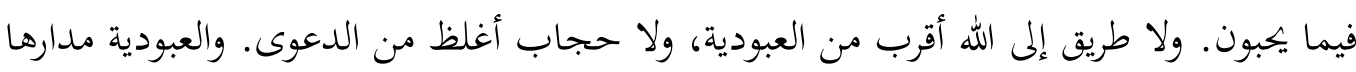
على قاعدتين هما أصلها حب كامل، وذل تام.

42 بديع الزمان سعيدا النورسي، المثنوى العربي النوري، (القاهرة: الطبعة السابعة، 2013)، ص. 307 43 ابن قيم الجوزية، مفتاح دار السعادة ومنشور ولاية العلم والإدارة...، ص. 433 المرجع السابق. 45 محمد بن أبي بكر بن أيوب بن سعد شمس الدين ابن قيم الجوزية، الوابل الصيب من الكلم الطيب...، 
والثالث، التوبة من الذنب، فإذا أراد الله بعبده خيراً فتح له من أبواب (التوبة) والندم

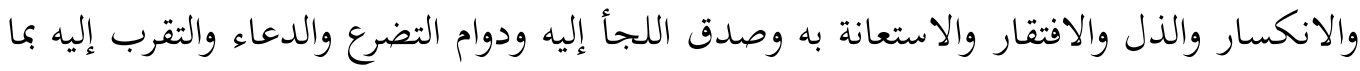
أمكن من الحسنات ما تكون تلك السيئة به رمته، حتى يقول عدو الله: يا ليتني تركته ولم أوقعه.

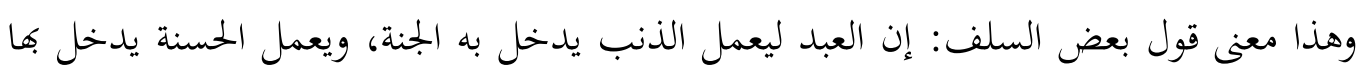
النار.

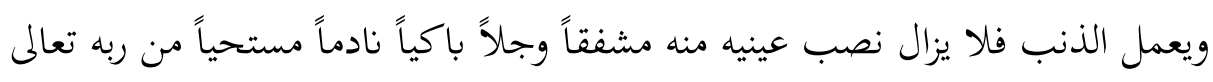

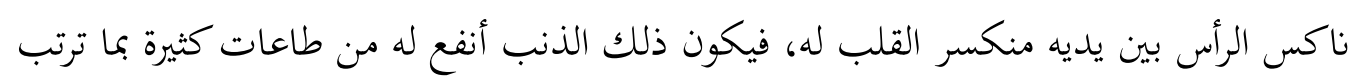

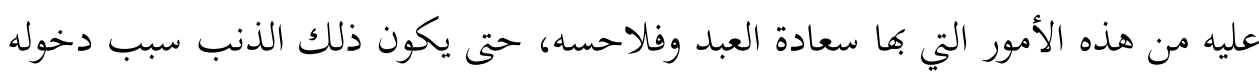
الجنة. 47

\section{3. التوحيد ودوره في تحقيق السعادة}

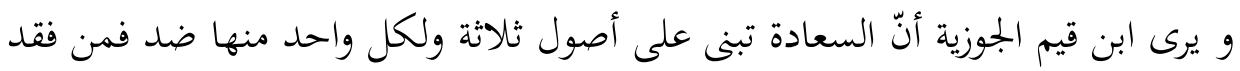

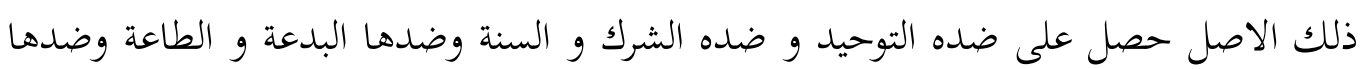

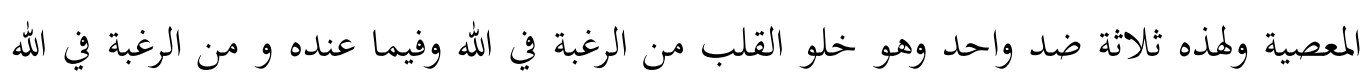
وفيما عنده ومن الرهبة منه ومما عنده.

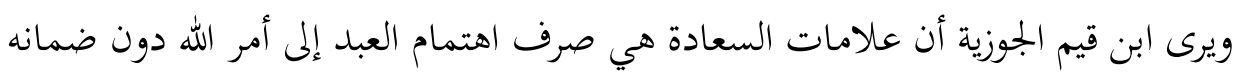

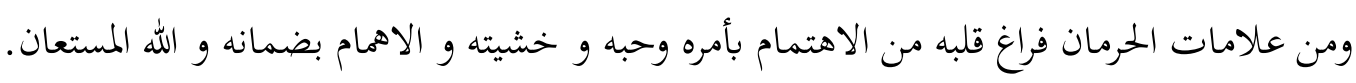

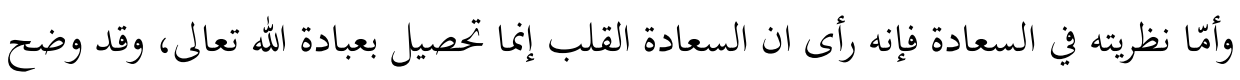

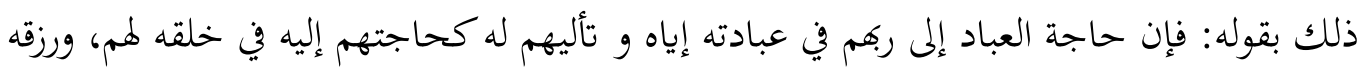

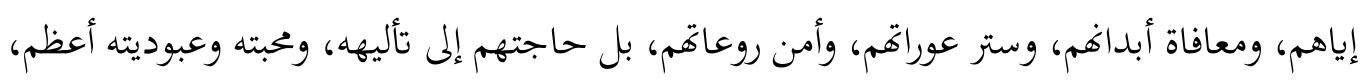

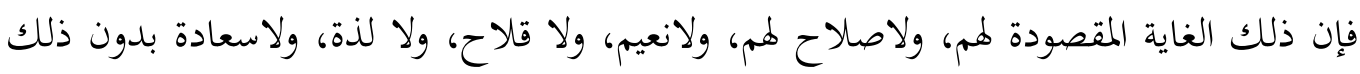

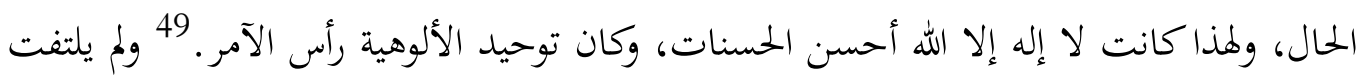

$$
46 \text { } 46 \text { المرجع السابق، ص.6 } 48 \text { المرجع السابق. }
$$

49 ابن قيم الجوزية، إغاثة الهفان، الطبعة الأولى، (د.م: دار عالم الفوائد، د.س)، ص. 15 
ابن القيم أن يستدل على ما ذكره في هذا الحال، فقال: ولهذا كان حق الله على عباده أن يعبدوه، ولا يشركون به شيئاً.

وابن قيم محق في تحميل القلب المسئولية، واعتباره مسئولا عن سلوك صاحبه إن جار أو

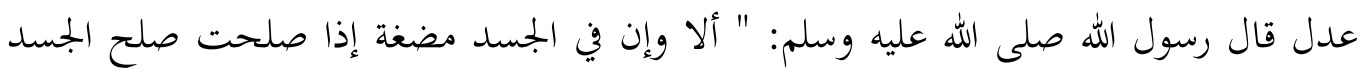
كله، وإذا فسدت فسد الجسد كله إلا وهي القلب". 50

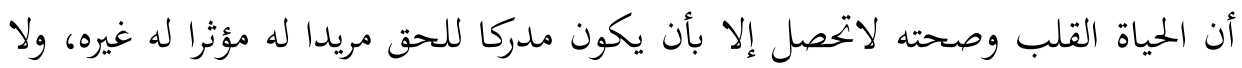

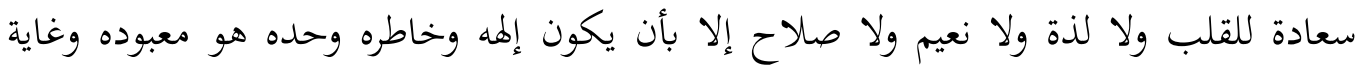
مطلوبه، وأحبّ إليه من كل ماسواه. 51

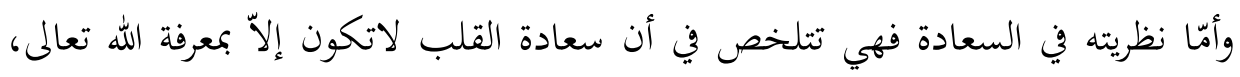

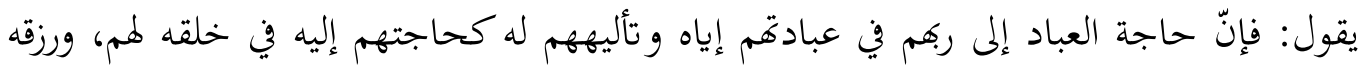

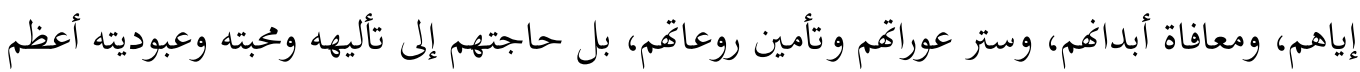

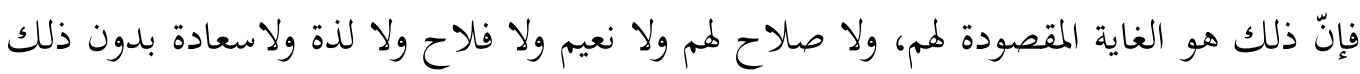

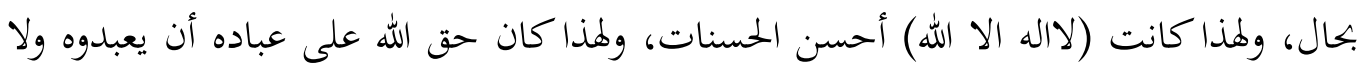
يشركوا به شيئا.

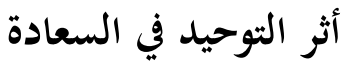

وبنى "إِيَّكَ نَعْبُدُ [الفاتحة: 5] " على أربع قواعد: التّحقِق بما يحبّه اللَّه ورسوله ويرضاه، من قول

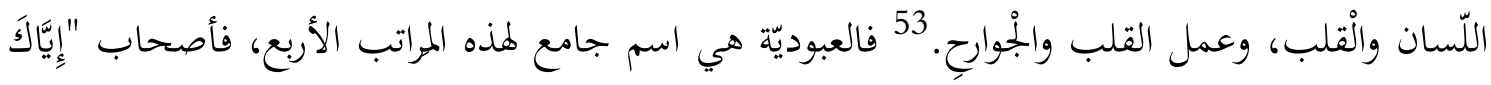
نَعْبُدُ [الفاتحة: 5]" حقّا هم أصحابها.

\footnotetext{
50 عبد العظيم عبد السلام شرف الدين، ابن قيم الجوزية عصره ومنهجه و آراؤه في الفقه والعقائد والتصوف، (كويت: الطبعة الثالثة 1405-1984)، ص.475 51 مصطفى مراد، موقف الإمام ابن قيم من الصوفية (القاهرة: الطبعة الأولى، 1312هـ-2000م)، ص.
}

$$
53 \text { م5 المرجع السابق، ص. } 250 \text { محد بن أبي بكر بن أيوب بن سعد شمس الدين ابن قيم الجوزية، مدارج السالكين...، ص. } 120
$$


فقول القلب هو اعتقاد ما أخبر اللَّه سبحانه به عن نفسه، وعن أسمائه وصفاته وأنفعاله وملائكته

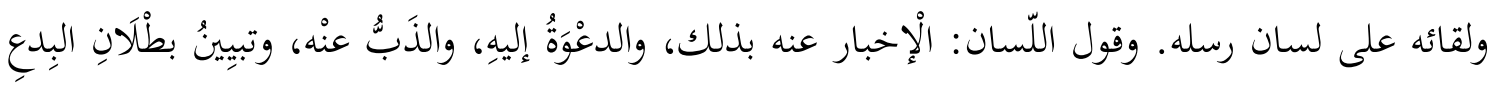

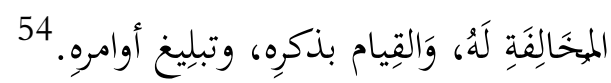

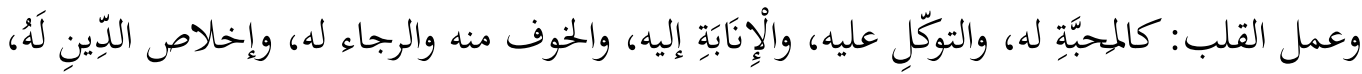

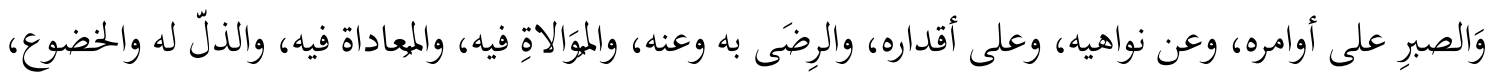

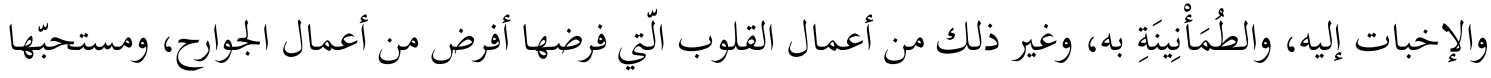

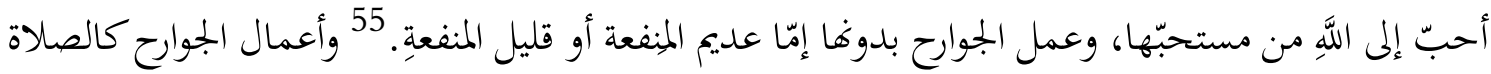
والجهاد، ونقل الأقدام إلى الجمعة والجماعات، ومساعدة العاجز، والإحسان إلى الحلق ونو ذلك.

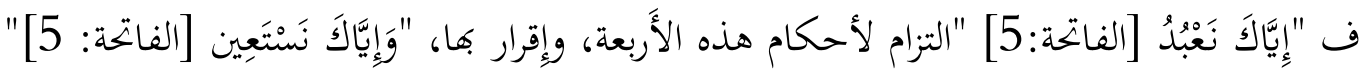

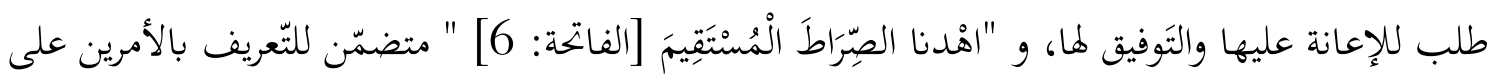

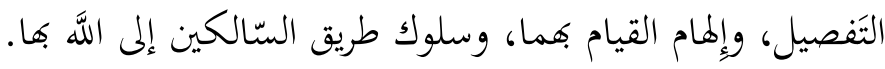

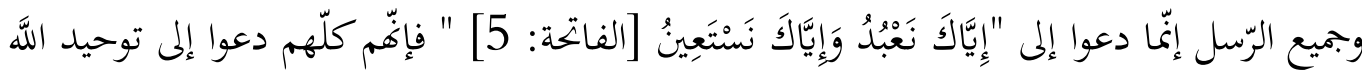

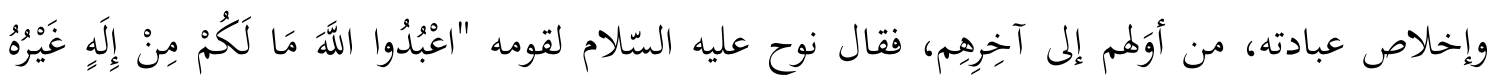

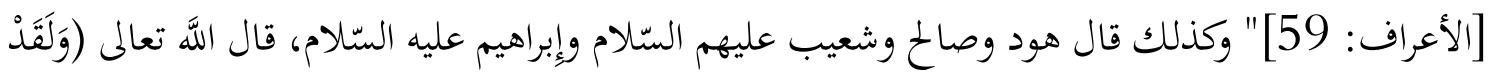

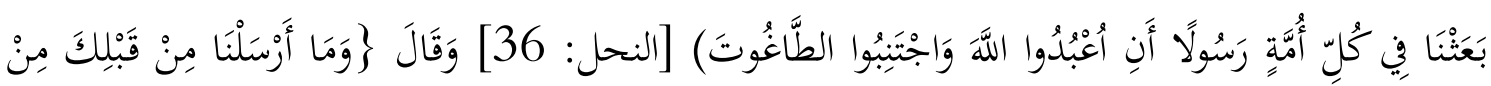

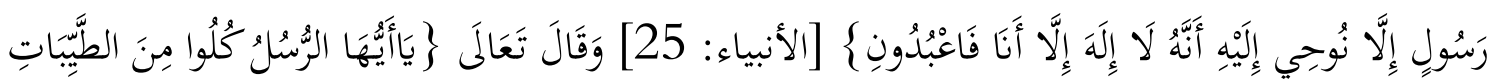

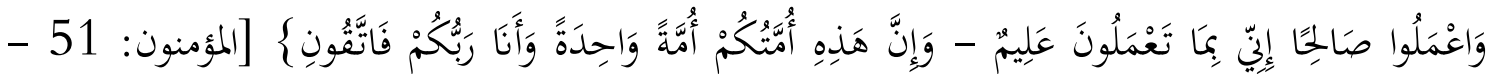

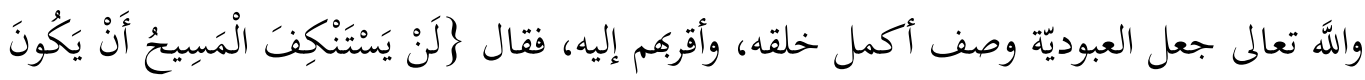

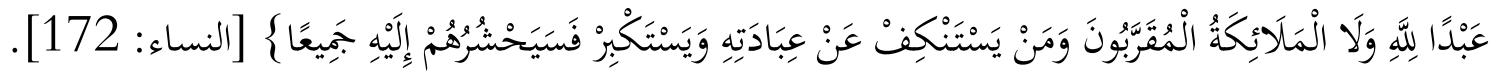

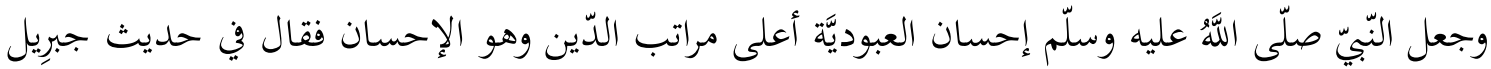

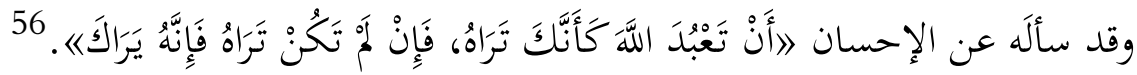

$$
55 \text { } 54 \text { المرجع السابق، ص. } 121 \text { المرجع السابق. }
$$


إنّ مفهوم التوحيد عند ابن قيم الجوزية بمعنى الإعتقاد بوحدانيّه تعالى وهو العلم والاعتراف بتفرّد الربّ بصفات الكمال، والإقرار بتوحده وصفاته العظمة والجلال، وإفراد وحده بالعبادة وأن يصدق بالقلب ويقرره باللسان والأعمال بالجوارح. كما قال النبي صلى الله عليه وسلم "من كان آخر كلامه لا إله إلا الله دخل الجنة". إنّ مفهوم السعادة عند ابن قيم الجوزية هي الشعور بالقرب إلى الله كأنّه ملقّى أمام ربه، رضا بما قسم الله عليه دون قلاقة القلب، بل بالقلب السليم، من الإيمان والعلم، ذلك يحصل بتمام العبادة أي تكميل مقام الذل والانقياد إلى الله تعالى ولا يشركه شيئ، لحصوله إلى معرفة الله. والسعادة ابن قيم الجوزية ينقسم إلى ثلاثة أقسام: الخارجية، الجسمية والبدانية، والسعادة النفسية والروحية القلبية. وكان أثر التوحيد في السعادة عنده ظهر في القلب السليم. ولوصول إلى السعادة، يرى من الإيمان والعلوم البشر لمعرفة الله. لأنّ حقيقة السعادة عنده التقرب إلى الله بالعبادة الخالصة، ولايشركه.

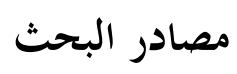

القرآن الكريم

الجليند، محمد السيد. قضية التوحيد بين الدين والفلسفة، القاهرة: مكتبة الشباب، الطبعة الرابعة، 1986 ه

الجوزي، ابن قيم، الفوائد، تحقيق: محمد بن أبى بكر أيوب الزرعي، ابو عبد الله، بيروت- دار الكتب العلمية. ، الجواب الكافي لمن سأل عن الدواء الشافي أو الداء والدواء، الطبعة الأولى، الجزء الأول، المغرب: دار المعرفة، 1997م.

، إغاثة الهفان في مصايد الشيطان، الطبعة الأولى،د.م: دار عالم الفوائد، د.س. ، مدارج السالكين بين منازل إياك نعبد وإياك نستعين. ، الجزء 3، بيروت-لبنان، دار

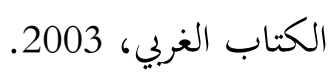


YAQZHAN | Volume 07, Nomor 02, Desember 2021

، مفتاح دار السعادة ومنشور ولاية العلم والإدارة، الجزء الأول، يبروت لبنان: دار الكتب العلمية، 1419 هـ.

، الوابل الصيب من الكلم الطيب، القاهرة: دار الحديث، سنة 1999 م.

الحنبلي، ابن رجب، كتاب التوحيد: رسالة كلمة الإخلاص وتحقيق معناها، الرياض: دار القاسم للتشر، ه 1415

الراوي، عمر أحمد، طب القلوب عند الإمامين الجليلين ابن تيمية الحراين و ابن قيم الجوزية، الطباعة الأولى، بيروت- لبنان: دار الكتب العلمية، 1424 هـ - 2003 م.

زركشي، أمل فتح الله، عقيدة التوحيد عند فلاسفة والمتكلمين والصوفية، فونوروكو: جامعة دار السلام كونتور، 2008.

العامري، عبد الله محمد غانم، السعادة في المنظور الإسلام، الطبعة الأولى، بيروت-لبنان: دار ابن حزم، .2005

عبد الفتاح، سعيد صديق، السعادة كما يراها المفكرون، بيروت- لبنان: مؤسسة عز الدين، دون السنة. عبده، محمد، رسالة التوحيد، القاهرة: الشعب، د. سنة. الغزإلي، أبو حامد، إحياء علوم الدين، الجزء الرابع، القاهرة: دارالحديث ، 1998، ، كيمياء السعادة، في مجموعة رسائل الإمام الغزالى، بيروت: دار الكتب العلمية، 1988.

القرضاوي، يوسف، الإيمان و الحياة، القاهرة: مكتبة وهبة، الطبعة العاشرة 1416 هـ. ، ملامح الجختمع المسلم الذي ننشده، مصر: مكتبة وهبة، الطبعة الثالثة 1422.

، حقيقة التوحيد، القاهرة: مكتبة وهبة، الطبعة السابعة، 1409 هـ.

شرف الدين، عبد العظيم عبد السلام، ابن قيم الجوزية عصره ومنهجه و آراؤه في الفقه والعقائد والتصوف، (كويت: الطبعة الثالثة 1405-1984. كثير، ابن، البداية و النهاية، ج. 14، قاهرة: سنة 14-8 هـ. محمد، مصطفي مراد صبحي، موقف الإمام ابن قيم من الصوفية، القاهرة: عين شمس، جميع حقوق الطبع محفوظة للناشر، الطبعة الأولى، سنة 141 هـ-2000 م. 
مسكويه، ابن، تُذيب الأخلاق في التربية، الطبعة الأولى، بيروت-لبنان: دار الكتب العلمية، 1405 هـم 1985

$$
\text { معلوف، أبو لويس، المنجد في اللغة والأعلام، بيروت: المكتبة الشرقية، 1986. }
$$

هلابي، صالح بن سعيد بن، لحات تاريخية من حياة ابن تيمية، مجلة اجامعة الإسلامية بالمدينة المنورة، د.ن.

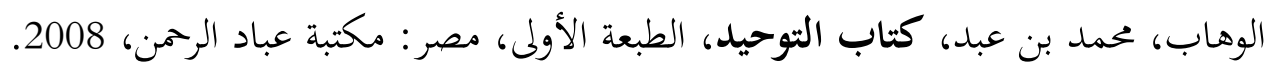

Departemen Pendidikan dan Kebudayaan, Kamus Besar Bahasa Indonesia, Jakarta: BalaiPustaka, 1990.

Madkour, Ibrahim, Filsafat Islam: Metode dan Penerapan, Terj. Yudian Wahyudi dkk, Jakarta:PT RajaGrafindo Persada, 1996.

Oishi, Shigehiro \& Ed Diener, Journal Association For Psychological Science, Vol. 2, Number 4, 2007.

Rakhmat, Jalaluddin, Renungan-Renungan Sufistik: Membuka Tirai Kegaiban, Bandung: PT. Mizan Pustaka, 1994.

Veenhoven, Ruud, “How Do We Assess How Happy We Are?", Paper Presented at Conference on 'New Directions in the Study of Happiness: United States and International Perspectives, University of Notre Dame, USA, October, 22-24, 2006. 